\title{
Identification and genetic characterization of equine infectious anemia virus in Western Balkans
}

Diana Lupulovic ${ }^{1 \dagger}$, Sara Savić ${ }^{\dagger \dagger}$, Delphine Gaudaire ${ }^{2}$, Nicolas Berthet ${ }^{3,4,5}$, Živoslav Grgić ${ }^{1}$, Kazimir Matović ${ }^{6}$ Alexandre Deshiere ${ }^{2}$ and Aymeric Hans ${ }^{2^{*}}$

\begin{abstract}
Background: Equine infectious anemia (EIA) is a viral disease, caused by the Equine Infectious Anemia virus (EIAV) belonging to the Retroviridae family, genus Lentivirus. Horses (or equids) infected with EIAV are lifelong carriers and they remain contagious for other horses even in the absence of clinical signs. So far, ElAV infection has been reported among horses in North and South America, France, Germany, Italy, Hungary and Romania, with no publication regarding the presence of EIAV in horses in Serbia. To determine the circulation of EIAV among, approximately, the 5000 horses of the Vojvodina region, northern part of Serbia, 316 serum undergone serological testing for EIA. Then, identification and full genome sequencing using next generation sequencing was performed from one ElA positive horse.
\end{abstract}

Results: the 316 sera were tested with 3 different commercial agar gel immunodiffusion (AGID) tests and two different commercial enzyme-linked immunosorbent assay (ELISA). With the three AGID kits, 311 (98.4\%) among the 316 tested sera were negative and only five (1.6\%) sera were positive for EIA. Some discrepancies were seen for the two ELISA kits tested since one exhibited the same results as AGID test and the second gave 295 sera with negative results, five with a positive result and 16 with doubtful outcome. Phylogenetic analysis performed using the full genome sequence showed that EIAV characterized from a horse in Serbia is different from those identify so fare around the world and form a distinct and separate group together with another EIAV strain.

Conclusions: This study demonstrate for the first time that EIAV is circulating at a low level in the horse population from the Northern part of Serbia. Interestingly, phylogenetic data indicates that this EIAV from the western Balkan region of Europe belongs to a new cluster.

Keywords: Equine infectious anemia, Horses, NGS, AGID test

\footnotetext{
*Correspondence: aymeric.hans@anses.fr

${ }^{\dagger}$ Lupulovic Diana and Savić Sara contributed equally to this work.

${ }^{2}$ ANSES- Laboratory for Animal Health in Normandy, Physiopathology and

Epidemiology of Equine Diseases Unit, Goustranville, France

Full list of author information is available at the end of the article
}

(c) The Author(s). 2021 Open Access This article is licensed under a Creative Commons Attribution 4.0 International License, which permits use, sharing, adaptation, distribution and reproduction in any medium or format, as long as you give appropriate credit to the original author(s) and the source, provide a link to the Creative Commons licence, and indicate if changes were made. The images or other third party material in this article are included in the article's Creative Commons licence, unless indicated otherwise in a credit line to the material. If material is not included in the article's Creative Commons licence and your intended use is not permitted by statutory regulation or exceeds the permitted use, you will need to obtain permission directly from the copyright holder. To view a copy of this licence, visit http://creativecommons.org/licenses/by/4.0/ The Creative Commons Public Domain Dedication waiver (http://creativecommons.org/publicdomain/zero/1.0/) applies to the data made available in this article, unless otherwise stated in a credit line to the data. 


\section{Background}

Equine infectious anemia (EIA) is a persistent viral infection of equidaes. The causative agent, EIA virus (EIAV) belongs to the genus Lentivirus from the Retroviridae family, subfamily Orthoretrovirinae. Genus Lentivirus also includes Human immunodeficiency virus (HIV), Bovine and Feline immunodeficiency viruses (BIV and FIV) as well as the Visna-maedi virus. Infected horses are lifelong carrier of the virus and remain contagious for other horses even without overt clinical signs. EIAV, a blood borne virus, is transmitted from one animal to another usually by hematophagous insects or iatrogenically through contaminated needles or dentistry equipment. Bloodsucking insects - primarily horse flies and stable flies - are mechanical vectors. Although the virus does not replicate within the insect, the virus remains infectious in its mouthparts for several hours after a bite. Equine infectious anemia has been reported in the USA, Canada, Latin America, Europe and Asia and affects horses, ponies, mules, and donkeys [1-7].

Pathogenesis of the disease is highly variable, reflecting a wide range of clinical forms of the disease - from unapparent infection to death. Once the horse is infected, several clinical forms are possible. Acute form of the disease is often associated with the primary infection and clinical symptoms include pyrexia, anorexia, depression, and petechial bleeding of the mucosa. Anemia is not typical as acute infection, except in very severe cases, in which epistaxis and ventral oedema may occur. Death of the animal can occur within 4 weeks after the primary infection. If the animal survives the acute phase, the frequency and the severity of the clinical episodes progressively drops, until the animal becomes an unapparent reservoir of the virus. Nevertheless, in the fields, some horses serologically positive to EIAV, have never manifested any clinical symptoms, or they were in such a mild form to remain unnoticed by owners. Diagnostics of EIA relies on the detection of antibodies against viral components and antibodies to EIAV can be detected using enzyme-linked immunosorbent assay (ELISA) and agar gel immunodiffusion (AGID) test. In Serbia, there is an annual monitoring system of the disease, carried out by the Ministry of Agriculture, Forestry and Water Management, Veterinary Directorate. According to this program, each horse, registered in Serbia, has to be tested for EIA once a year. However, horses used for the production of biological materials, such as hyperimmune sera or vaccines, have to be tested twice a year. Moreover, when the owner is selling or on any other way alienating the animal, they have to present a certificate, not older than 30 days, stating that the horse is negative for EIA. The main serological diagnostic assay used in Serbia for EIAV testing is AGID test and, in parallel, ELISA test may be used but should be confirmed by an
AGID test in case of positive finding. Equine infectious anemia is a notifiable disease in Serbia and all EIAV positive horses are reported to Veterinary Directorate and OIE. EIA positive horses are euthanized according to the Serbian legislation. The aim of this study is to report, for the first time, the seroprevalence of EIAV in Serbian horses and its molecular characterization using next generation sequencing of EIAV of horses from Vojvodina region (Northern part of Serbia).

\section{Results \\ Serological results}

Between 1994 and 2013, a total of 11,972 horses serum samples were analysed using AGID tests. The obtained results show that 21 horses were found positive for EIA in the region of southern Backa and Srem in Serbia. The percentage of EIA positive horses in this 20-year period represents only $0.17 \%$ of the tested horses. Another study was undertaken to validate the use of some ELISA tests, under field conditions, compared to the AGID kit used routinely in the Serbian laboratory from VMRD company. For this purpose, 316 samples collected during two-year period (2013-2014) in the northern part of Serbia (Fig. 1) were tested first with three different commercial AGID kits (Idexx, ID-Vet and VMRD). The results obtained with the three AGID kits were the same with 311 out of 316 sera negative for EIA and only 5 (1.6\%) samples positives for EIA. Those results indicated that the three commercial AGID kits tested exhibit the same outcome. In a second step, the 316 serum samples were also tested with 2 commercial ELISA kits (Synbiotics and VMRD). The ELISA kit from Synbiotics was able to find the same results as the AGID kits previously tested. However, the VMRD ELISA kit gave 295 sera with negative results, 5 with a positive results and 16 with doubtful outcome. Those results indicate that the two ELISA kits tested in this study could be used in diagnostic laboratories given that all positive or doubtful samples in ELISA should be retested and confirmed in AGID test as previously described [8].

\section{Virus genotyping}

Furthermore, the spleen of one horse out of 5 found positive between 2013 and 2014 was able to be collected after euthanasia. The full genome sequence of the EIA virus (EIAV-SERB-1) from this horse was performed using the targeted sequence enrichment and next generation sequencing as described previously [9]. This sequence was compared to the 23 full genome sequences of EIAV published so far in the literature from England (EIAV-COV and EIAV-DEV), USA (Wyo, Uk, V26 and V70), Japan (EIAV-Miya), Ireland (F2, F3, F4 and H3), Italy (SA and DE), France (EIAV-FR-15 and FR-16), China (Liao, LN1, DV3-5, FDDV, DLA and DLV2-6) 


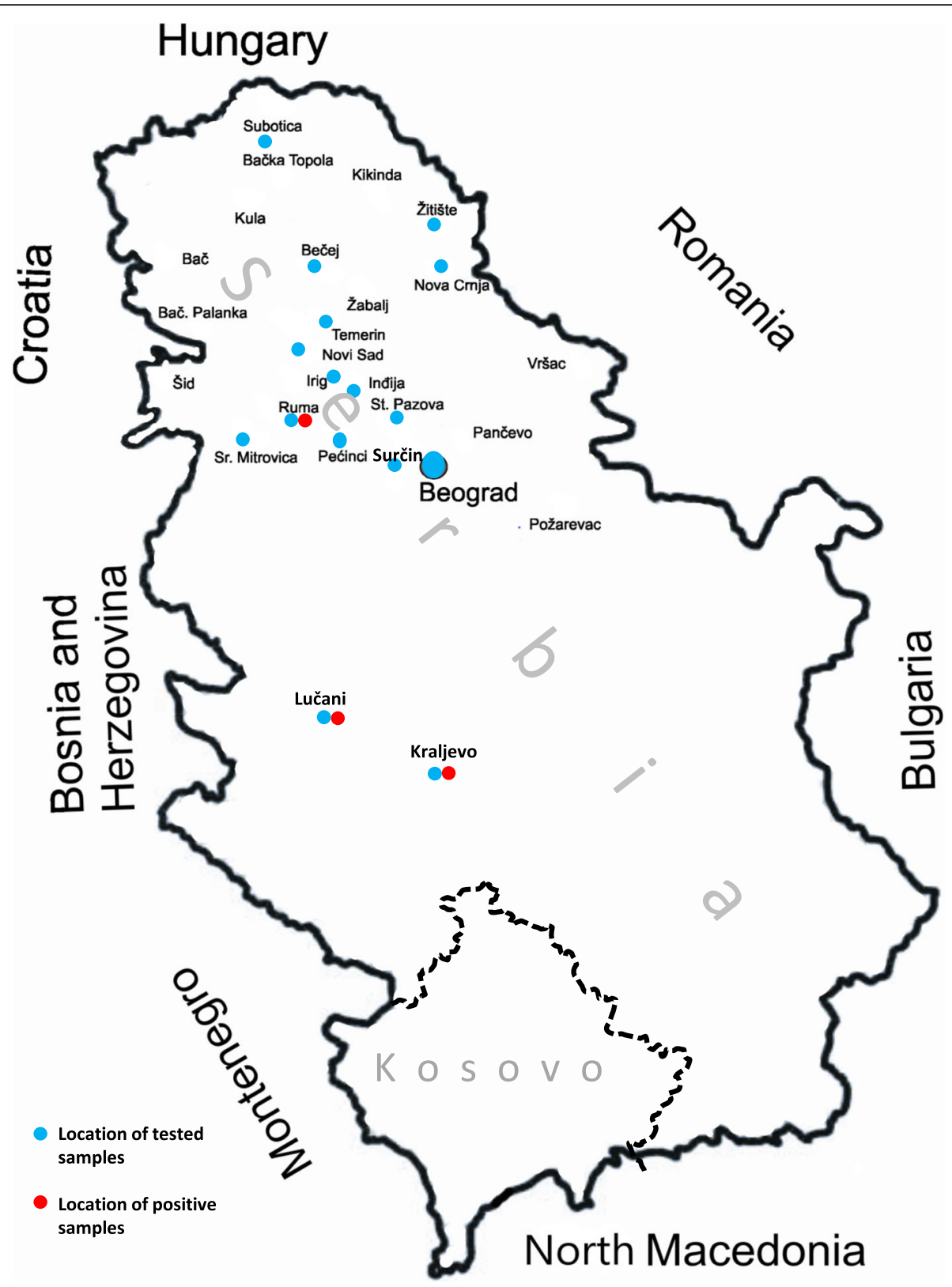

Fig. 1 Geographic distribution of collected samples between 2013 and 2014 that have been tested for equine infectious anemia infection in the Northern part of Serbia. The map is an own creation

and Brazil [9-13]. Interestingly, the phylogenetic tree (Fig. 2) revealed that EIAV-SERB-1 form a new branch with the strain EIAV-FR-16 isolated in 2014 in France from an asymptomatic Friesian stallion. The nucleotides comparison study indicates that this two EIA isolates, EIAV-SERB-1 and EIAV-FR-16, share $78.7 \%$ of identity. However, epidemiological investigation did not established any relationship between those two cases.

\section{Discussion}

The outbreaks statements in the north part of Serbia over the last 20 years (1993-2013) were rather sporadic, without cases declared during some years, and with only few EIA positive horses diagnosed each time. Those results seem to indicate that EIA does not widespread in the Vojvodina region of Serbia which has border with Romania, which is known as endemic country for EIAV. 


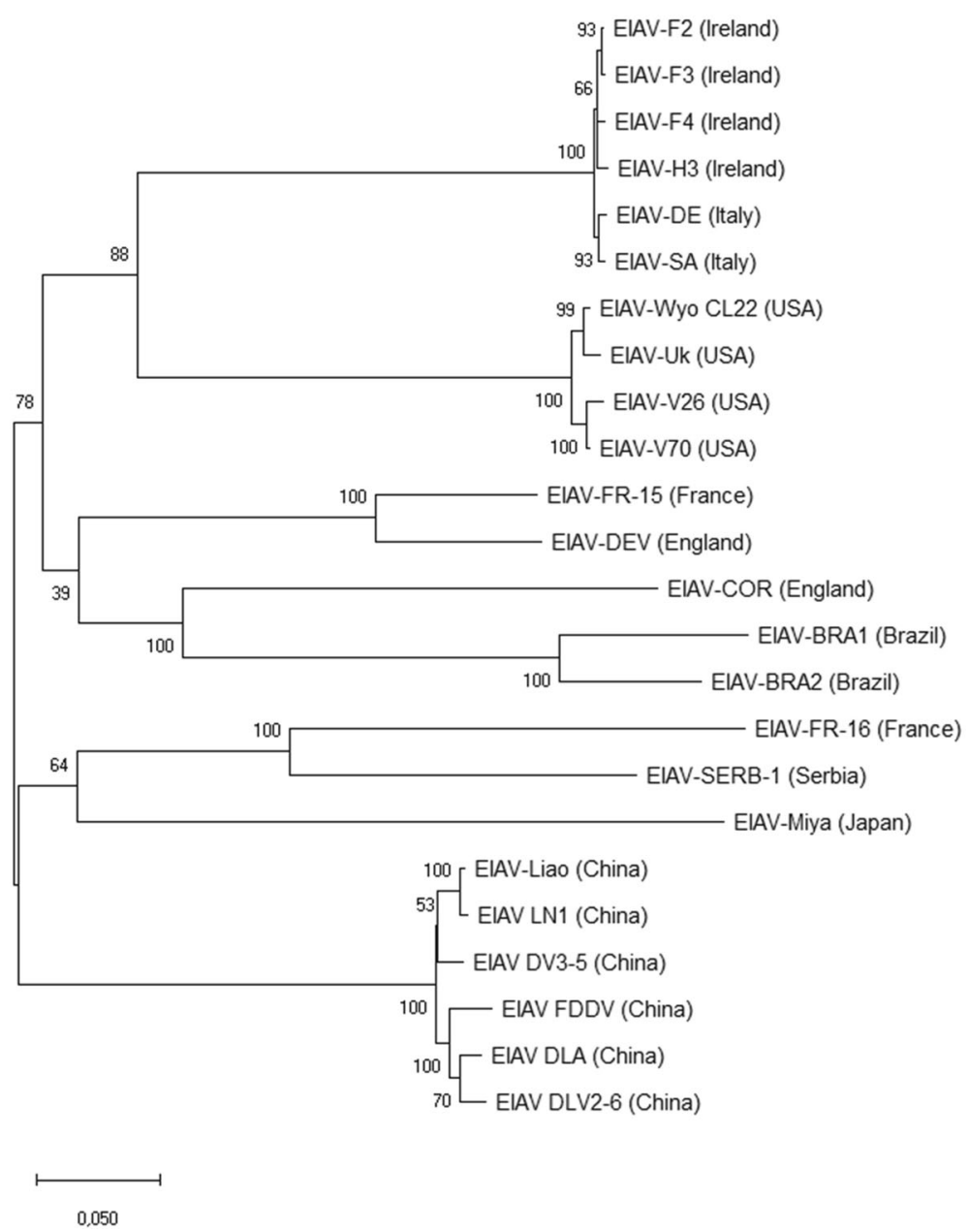

Fig. 2 The evolutionary history was inferred by using the Maximum Likelihood method based on the Tamura-Nei model. The percentage of trees in which the associated taxa clustered together is shown next to the branches. The analysis involved 24 ElAV full genome sequences. All positions containing gaps and missing data were eliminated. There were a total of 7269 positions in the final dataset. Evolutionary analyses were conducted in MEGA7

Moreover, we observed that the 24 EIAV isolates fully sequenced and described so far in the scientific literature can be divided into 6 different clades or groups. One branch represents EIAV characterized from outbreaks declared in Ireland and Italy in 2006, a second branch is composed of viruses coming from the USA which include the Wyoming reference strain. Two more branches of the phylogenetic tree represent viruses isolated from horses in China and in Japan. The two last branches are composed from EIA viruses recently characterized in France, England and Serbia. Those results indicate that EIAV isolates can be divided, at least, in 6 distinct clades, based on the full EIAV genome sequences, which do not represent the geographical origin of the infected horses since 3 of them are composed of viral isolates retrieved from horses held in Europe.

\section{Conclusions}

In conclusion, the data presented in this study indicate that EIA is present in the horse population of Serbia at a low level, certainly thanks to the surveillance program implemented by Serbian authority since 1981 [14]. This low EIA occurrence allows the use of ELISA test to facilitate the screening test for the annual EIA surveillance program in Serbia given that all positive sample with ELISA should be confirmed with AGID test. Moreover, our findings reinforce the large diversity of EIAV isolates characterized around the world during the last decade and it is the first study to demonstrate the presence of EIAV in Serbia associated to the full genome sequence characterization using NGS.

\section{Methods}

\section{Blood samples}

A total number of 11,972 horse sera samples, collected from 1994 to 2013, were analyzed for EIA using agar gel immunodiffusion test (AGID) as described by the World Organization of Animal Health (OIE) chapter 2.5.6. The 
samples of horses analysed were from two different regions of Serbia southern Backa and Srem. Sera samples from 316 horses, held in the Province of Vojvodina in Serbia, were collected between 2013 and 2014.

\section{Serological testing with AGID and ELISA kits}

Sera have been tested with 3 different commercial AGID test (Idexx, ID-Vet and VMRD) following manufacturer's instructions in two different laboratories (ANSES-Laboratory for animal health which is the European Reference laboratory for equine diseases other that African sickness and Scientific Veterinary Institute "Novi Sad", Department for serology, immunology and biochemistry) and two different commercial ELISA tests (Synbiotics and VMRD) as recommended by manufacturer.

\section{Spleen sample, viral genome sequencing and phylogenetic analysis}

Horses were subject to euthanasia as enforce by the Serbian legislation as follow, an intravenous injection of the anaesthetic Xilazin 2\% was performed. The usual dose of Xilazin for anaesthesia is $1,1 \mathrm{mg} / \mathrm{kg}$, so for a horse that weight $500 \mathrm{~kg}$ half a dose would be $12-15 \mathrm{ml}$ of Xilazin $2 \%$ just for sedation. The horse became very quiet in several minutes. Then a mix of euthanizing substances (T61) was injected intravenously to the EIA infected horses. For a horse of $500 \mathrm{~kg}$ it should be a dose of 50 $\mathrm{ml}$. After $20-30 \mathrm{~s}$, the horse just kneeled down and then slowly lied to the side. There was no excitation, no nervous reactions. Once the death is confirmed by the official veterinarian, spleen from one EIA positive horse was collected and kept at $-80^{\circ} \mathrm{C}$ until use. Genomic DNA from collected spleen was extracted as previously described [4]. DNA libraries were prepared using the SureSelect XT Library preparation kit for Illumina Multiplexed sequencing Kit (Agilent Technologies, Santa Clara, CA, USA) as described previously [9] and subjected to multiplex deep sequencing on the MiSeq platform using the MiSeq Reagent Kit V2 (Illumina). Fastq format files from each viral genome were trimmed and paired reads were merged using the Geneious Prime sequencing data analysis software (Biomatters LTD, Auckland, New Zealand) [15]. Contigs were obtained by alignment to the reference genome EIAV F2 (GenBank accession number: JX480631.1). Phylogenetic reconstruction was carried out using the MEGA software version 7 [16]. Nucleotide and amino acid identities were calculated using MegAlign from DNA star software.

\section{Abbreviations}

AGID: Agar Gel ImmunoDiffusion; BIV: Bovine Immunodeficiency Virus; EIA: Equine Infectious Anemia; EIAV: Equine Infectious Anemia Virus; ELISA: Enzyme-linked ImmunoSorbent Assay; FIV: Feline Immunodeficiency Virus; HIV: Human Immunodeficiency Virus; OIE: World organization for animal health; USA: United States of America

\section{Aknowledgments}

The authors thank the sequencing platform SeSAME of the Centre François Baclesse in Caen, Normandy and official veterinary services in Serbia. Laboratoire de santé animale, site de Normandie is a member of the GIS Centaure equine research and authors thanks Regional Council of Normandy, France for providing an excellent scientific environment.

\section{Authors' contributions}

Conceptualization: LD, SS, HA. Methodology: SS, GD, DA. Formal analysis and investigation: LD, SS, GD, BN, GŽ, MK, DA, HA. Writing - original draft: SS, HA. Writing - review \& editing: LD, SS, GD, BN, HA. Funding acquisition: LD, HA. Resources: LD, HA. Supervision: LD, HA. All the authors have read and approved the manuscript.

\section{Funding}

This study was supported by the Hubert Curien Partnerships (PHC-Pavle Savic), the European Reference Laboratory for Equine Diseases other than African Horse Sickness, ANSES's own institutional resources and the Ministry of Science and Technological Development of the Republic of Serbia (Grant no. TR31071). Alexandre Deshiere and "CENTAURE project" was supported by a grant awarded by the Regional Council of Normandy and the French Ministry of Higher Education, within the framework of CPER 2015-2020 and FEDER/FSE 2014-2020. Nicolas Berthet is also supported by the Chinese Academy of Sciences and a Shanghai Municipal Science and Technology Major Project (Grant No. 2019SHZDZX02). The funders had no role in study design, data collection and interpretation, or the decision to submit the work for publication.

\section{Availability of data and materials}

The datasets used and/or analysed during the current study are available from the corresponding author on reasonable request. Sequence from this study has been deposited in NCBI Genbank under the following accession number MT 338937

\section{Declarations}

Ethics approval and consent to participate

No ethical approval was required since this study is dealing with naturally infected horses. EIA is a notifiable diseases in Serbia, as such the Serbian legislation enforce euthanasia of EIA positive horses as described in The Rule Book of Measures for control and eradication of Infectious Anemia in horses Section 7 ("SI. List SFRJ", br. 39/88). In this context, blood and organ collection from EIA positive horse have been performed following strictly the Serbian authority regulation regarding Equine infectious anemia which approved the collection of samples from ElA infected horses.

Consent for publication

Not applicable.

\section{Competing interests}

The authors declare that the research was conducted in the absence of any commercial or financial relationships that could be considered as a potential conflict of interest.

\section{Author details}

'Scientific Veterinary Institute "Novi Sad", Rumenacki put 20, Novi Sad 21000, Serbia. ${ }^{2}$ ANSES- Laboratory for Animal Health in Normandy, Physiopathology and Epidemiology of Equine Diseases Unit, Goustranville, France. ${ }^{3}$ The Center for Microbes, Development and Health, CAS Key Laboratory of Molecular Virology and Immunology, Institut Pasteur of Shanghai - Chinese Academy of Sciences, Discovery and Molecular Characterization of Pathogens, Shanghai, China. ${ }^{4}$ Institut Pasteur, Unité Environnement et Risque Infectieux, Cellule d'Intervention Biologique d'Urgence, Paris, France. ${ }^{5}$ Chinese Academy of Sciences, Shanghai 200031, China. ${ }^{6}$ Specialist veterinary institute Kraljevo, Zicka 34, Kraljevo, Serbia. 
Received: 7 October 2020 Accepted: 24 March 2021

\section{Published online: 15 April 2021}

\section{References}

1. Cursino AE, Vilela APP, Franco-Luiz APM, de Oliveira JG, Nogueira MF, Junior JPA, et al. Equine infectious anemia virus in naturally infected horses from the Brazilian Pantanal. Arch Virol. 2018;163(9):2385-94.

2. Tigre DM, Brandao CF, de Paula FL, Chinalia FA, Campos GS, Sardi SI. Characterization of isolates of equine infectious anemia virus in Brazil. Arch Virol. 2017;162(3):873-7.

3. Sharav T, Konnai S, Ochirkhuu N, Ts EO, Mekata H, Sakoda Y, et al. Detection and molecular characterization of equine infectious anemia virus in Mongolian horses. J Vet Med Sci. 2017;79(11):1884-8.

4. Gaudaire D, Lecouturier F, Poncon N, Morilland E, Laugier C, Zientara S, et al. Molecular characterization of equine infectious anaemia virus from a major outbreak in southeastern France. Transbound Emerg Dis. 2018;65(1): e7-e13.

5. Cappelli K, Cook RF, Stefanetti V, Passamonti F, Autorino GL, Scicluna MT, et al. Deep sequencing and variant analysis of an Italian pathogenic field strain of equine infectious anaemia virus. Transbound Emerg Dis. 2017;64(6): 2104-12.

6. Kuhar U, Malovrh T. High genetic diversity of equine infectious anaemia virus strains from Slovenia revealed upon phylogenetic analysis of the p15 gag gene region. Equine Vet J. 2016;48(2):205-10.

7. Nagarajan MM, Simard C. Gag genetic heterogeneity of equine infectious anemia virus (EIAV) in naturally infected horses in Canada. Virus Res. 2007; 129(2):228-35.

8. Nardini R, Autorino GL, Issel CJ, Cook RF, Ricci I, Frontoso R, et al. Evaluation of six serological ELISA kits available in Italy as screening tests for equine infectious anaemia surveillance. BMC Vet Res. 2017;13(1):105.

9. Deshiere A, Berthet N, Lecouturier F, Gaudaire D, Hans A. Molecular characterization of equine infectious Anemia viruses using targeted sequence enrichment and next generation sequencing. Virology. 2019;537: $121-9$.

10. Dong JB, Zhu W, Cook FR, Goto Y, Horii Y, Haga T. Identification of a novel equine infectious anemia virus field strain isolated from feral horses in southern Japan. J Gen Virol. 2013;94(Pt 2):360-5.

11. Quinlivan M, Cook F, Kenna R, Callinan JJ, Cullinane A. Genetic characterization by composite sequence analysis of a new pathogenic field strain of equine infectious anemia virus from the 2006 outbreak in Ireland. J Gen Virol. 2013;94(Pt 3):612-22.

12. Dorey-Robinson DLW, Locker N, Steinbach F, Choudhury B. Molecular characterization of equine infectious anaemia virus strains detected in England in 2010 and 2012. Transbound Emerg Dis. 2019;66(6):2311-7.

13. Wang L, Tong G, Liu H, Yang Z, Qiu H, Kong X, et al. Proviral genomic sequence analysis of Chinese donkey leukocyte attenuated equine infectious anemia virus vaccine and its parental virus strain Liaoning. Sci China C Life Sci. 2002:45(1):57-67.

14. Vidić B, Lazić S, Milanov D, Grgić Ž. Ispitivanje rasprostranjenosti pojedinih zaraznih bolesti konja u Vojvodini.Zbornik radova, 7.Kongres veterinara Jugoslavije, Beograd, 27-29.oktobra, Beograd, Savez veterinara Jugoslavije, 1998. p. 534

15. Kearse M, Moir R, Wilson A, Stones-Havas S, Cheung M, Sturrock S, et al. Geneious basic: an integrated and extendable desktop software platform for the organization and analysis of sequence data. Bioinformatics. 2012;28(12): $1647-9$.

16. Kumar S, Stecher G, Tamura K. MEGA7: molecular evolutionary genetics analysis version 7.0 for bigger datasets. Mol Biol Evol. 2016;33(7):1870-4.

\section{Publisher's Note}

Springer Nature remains neutral with regard to jurisdictional claims in published maps and institutional affiliations.

Ready to submit your research? Choose BMC and benefit from:

- fast, convenient online submission

- thorough peer review by experienced researchers in your field

- rapid publication on acceptance

- support for research data, including large and complex data types

- gold Open Access which fosters wider collaboration and increased citations

- maximum visibility for your research: over $100 \mathrm{M}$ website views per year

At BMC, research is always in progress.

Learn more biomedcentral.com/submissions 